Society for the Anthropology of Work • Policing and Labor

\title{
On the Workaday Origin of Police Callousness
}

David Sausdal

Published on: Dec 01, 2020

DOI: $10.21428 / 1 \mathrm{~d} 6$ be30e.8d8aeb1d

License: Creative Commons Attribution 4.0 International License (CC-BY 4.0). 
Police officers are brutal. They are cynics and xenophobes who do and say offensive things. This is, at least, a description often found in both popular and scholarly portrayals. Mostly, researchers have argued that this has to do with the broad reach of a specifically crude "police culture" (Cockcroft 2020). Indeed, whether you go to India (Jauregui 2016), France (Fassin 2013), the Netherlands (Mutsaers 2019), Scandinavia (Høigård 2005), the United Kingdom (Loftus 2009), or the United States (Manning and Van Maanen 1978), crude and callous behavior can reportedly be found among police officers.

In this short essay, I do not refute the widespread existence of a too often deeply problematic police culture. Looking at many recent examples of police misconduct and violence, this would be foolish. Yet I want to suggest that our theories about why this is so could do with a better grounding in the particularities of police officers' workaday lives (see also Fassin 2017; Sausdal 2020a). As my studies of Danish police detectives who investigate property crimes often committed by foreign nationals have shown me (Sausdal 2018a, 2018b, 2019a, 2019b, 2020b), disrespectful, discriminatory, and violent behavior by the police cannot be understood in straightforwardly individual or structural terms. That is, police callousness cannot exclusively be attributed to the presence of a proverbial "bad apple" (Bowling et al. 2004: 8). Nor is it solely an expression of a depraved organizational culture, nor simply the ugly outcome of wider institutional and societal sentiments. No, what manifests itself as police callousness also has to do with phenomena that are far more commonplace, yet just as consequential. In particular, I argue, it is also caused by certain workaday tasks and practices-tasks and practices that, importantly, are not only carried out but often cared about by police officers in ways that demand to be better understood.

\section{Fun Encounters}

Though often portrayed as sinister, police officers like to have fun. They tell jokes and are known adrenaline junkies (van Hulst 2013). Such sources of excitement are one way that police officers find pleasure in their work. But during a normal workday officers, much like other professionals, find gratification in less evocative and more routine aspects of their jobs. Indeed, these "pleasures of policing" (Sausdal 2018b) are just as much, if not more than moments of excitement, what keeps officers happy and professionally invested. Here is a telling example from my field notes:

"Follow me," Detective Jensen said, "we're going downstairs to meet a gentleman who wants his things back." I did as told and followed Jensen down three flights of stairs to the entrance of the North Zealand police station. Here, a broad and buzz-cut man in his mid-twenties was waiting for us. Jensen offered his hand and so did the man, who I later learned was a member of the Hells Angels. “How's it going?” Jensen asked. “I see we don't have you locked up anymore." The man laughed. "Nah, got out on good behavior. Living an honest life now!" "That sounds perfect. Just what we cops like to hear!" Jensen responded with a smile. For the next ten minutes, their 
conversation carried on, culminating with Jensen asking some more professional questions. In conclusion, he handed the Hells Angel his belongings, which had been seized as part of the investigation that had gotten him convicted. "See you soon," Jensen shouted as the man left. Turning around, with a sneaky grin, the man answered: “We'll see about that, my friend!" Jensen laughed and we walked upstairs again. "You see, David," he said to me, "we might as well have some fun when doing our work - you know, banter a little, get to know one another and get the information we need. Policing simply becomes too burdensome if it's only strictly business."

In my ethnographic study of Danish detectives and their efforts to apprehend and convict burglars, robbers, trick thieves, pickpockets, and credit card fraudsters, I frequently observed scenes like the one described above. Though the circumstances differed, it was not unusual to find detectives having jesting conversations with suspects and civilians of pretty much all creeds and colors, coupled with a more serious investigative approach. ${ }^{1}$ This mingling of business and pleasure could be seen when returning belongings to suspects, when meeting them on the street, during formal interrogations, or even when arresting them.

\section{Frustrating Encounters}

However, in the detectives' encounters with some suspects, the story was a different one. Here, there was hardly any jesting or conversing, not much interaction at all beyond conveying the fact that they were suspected of a crime. If the suspect was, for example, from Poland, Morocco, or Chile (Sausdal 2014), then the encounters between suspect and officer were almost always "strictly business," in Detective Jensen's words. Surely, there are many explanations of why this was the case, including wellrehearsed ideas about how officers worldwide tend to treat foreigners and other minorities in discriminatory ways, seeing them as antagonists and even "assholes" (Van Maanen 1978). Though such prejudice played its part, a number of recurrent observations provided me with a supplementary way of understanding this pattern.

For instance, I frequently found detectives complaining about how frustrating it was to conduct interviews and interrogations when their suspect was a non-Danish-speaking foreigner. As few of the foreign suspects spoke Danish or English, the language barrier made it almost impossible for detectives to strike up more informal conversations. As one detective described it: "Normally, I invite them for a smoke and a chat, getting them to relax and to talk about things in a less formal setting." The language barrier however meant that an interpreter had to be present throughout the interaction, making it, in the words of another detective:

... very staccato and difficult to conduct and control. I mean, instead of us having a conversation about the whole thing, it's like a questionnaire ... like a boring Q\&A, with me not really knowing what's being said.... It makes the quality of the interview worse and it makes it difficult for me 
to have a feel for the situation, noticing those small gestures. Honestly, policing foreigners is often a shit job; it's less giving in a professional sense but also just less fun. It turns something gratifying into something frustrating.

Indeed, this turn from gratification to disgruntlement was a recurring factor in the Danish detectives' policing of foreigners - a frustrating turn that not only made their job feel less satisfying, but that often spilled over into the detectives thinking less of those who were causing this to happen.

I found similar dynamics at work when I was observing how detectives approached the monitoring of wiretaps on Danish-speaking suspects as compared to non-Danish speakers (Sausdal 2018b). While all wiretaps involve tedium, listening to never-ending hours of random chatter, the detectives did appreciate how they afforded contextual insight into suspects' everyday lives. "Listening in," as one detective put it, "provides us with useful information in terms of our investigation, but it also gives us a nice and broader understanding of the people we are dealing with." "When it's a foreigner," he went on:

... we [however] need an interpreter, who will most often only translate the case-related criminal matter. In this way, I never get the bigger picture but only the criminal one $\ldots$ This might be why I like catching Danes. I get the bigger picture ... If his name's Petrescu [used here as a typical Romanian surname] or something, I'll probably be less understanding. (Sausdal 2018b: 237)

Because the officer would not get the bigger picture, he would also be less sympathetic toward the Romanian suspect.

What examples like these suggest is that detectives' negativity toward foreign nationals was not just a matter of stereotypical prejudice; it was also a matter of everyday (and, to them, enjoyable) aspects of their work turning sour, providing them with less gratification in their jobs and depriving them of the opportunity to think of foreign suspects in more than criminal terms. Depressingly, as I have argued elsewhere (Sausdal 2019a), it was the same crude simplification of their everyday work-a process that occurred more frequently when working with foreigners - that led detectives to become more abusive and even violent. Without the means, whether in practice or through proxies such as national records and registries, to see certain suspects as human beings for better or for worse, the police to "other" and dehumanize them. In Zygmunt Bauman's words, the simplification of the detectives' everyday work led to a "moral blindness" (Bauman and Donskis 2013) - a moral blindness that not only found its expression in their work, but was arguably caused by the work itself. 


\section{Concluding Perspectives: Strategies for Change?}

What might my ethnography of detective work, when considered alongside similar studies of police forces unconstrained by the values of the Danish welfare state (e.g., Muir 1977; Feldman 2019), tell us about policing? More particularly, what does it tell us in terms of strategies for positive change?

At the turn of the twenty-first century, scholars of policing took an optimistic view as they looked at initiatives to reform the police and get more minorities employed, as well as other ways of acknowledging and dealing with problems of police (mis)conduct. Finally, things seemed to be changing. But, unfortunately, more recent studies have largely thwarted that hope, showing that no amount of alternative recruitment, training, or reform has been able to fully address the callousness of police culture (Loftus 2009; Karpiak and Garriott 2018).

At the risk of advancing yet another unfruitful proposal, I will end this essay by daring to suggest a different strategy for change. Fundamentally, I would recommend that (even more) attention be paid to how everyday police work, especially involving those who too often fall prey to police misconduct, can be made more meaningful from the police officer's viewpoint. How can we help officers to see suspects as more than criminal, beyond the occasional sensitivity training or executive dictum? Or, better, how can daily police work be organized so that it involves not a simplification but a humanization of those who are policed? Asking and answering such questions is difficult. And, surely, a more humanizing arrangement of everyday police work will not suddenly do away with ingrained police prejudice. It nevertheless seems important to pose such questions, insofar as present-day and future policing will increasingly involve practices and technologies that serve to further distance officers from the public (Bigo and Guild 2005).

In this day and age, it may seem provocative to advocate for making police work more meaningful and, in reference to police misconduct, helping the offender rather than the offended. Then again, in other areas of criminology and criminal justice, improving the life conditions of potential offenders to turn them away from crime is not-at least not always - seen as controversial. The goal here is the same: deterring bad behavior.

\section{Notes}

1. The existence of a jesting or joking relationship has also been noted in many other police studies across the world (see van Hulst 2013). However, research has rarely looked at the gendered aspect of this dynamic in terms of whether it also applies to women suspects and civilians, an issue that I have also not properly explored. 


\section{Preview Image}

Photo by Chris Henry.

\section{References}

Bauman, Zygmunt, and Leonidas Donskis. 2013. Moral Blindness: The Loss of Sensitivity in Liquid Modernity. Malden, MA: Polity.

Bigo, Didier, and Elspeth Guild. 2005. "Policing at a Distance: Schengen Visa Policies." In Controlling Frontiers. Free Movement into and within Europe, edited by Didier Bigo and Elspeth Guild, 233-63. Burlington, VT: Ashgate.

Bowling, Benjamin, Coretta Phillips, Alexandra Campbell, and Maria Docking. 2004. "Policing and Human Rights: Eliminating Discrimination, Xenophobia, Intolerance and the Abuse of Power from Police Work." Identities, Conflict and Cohesion Programme, Paper no. 4. Geneva: United Nations Research Institute for Social Development.

Cockcroft, Tom. 2020. Police Occupational Culture: Research and Practice. Bristol, UK: Policy Press.

Fassin, Didier. 2013. Enforcing Order: An Ethnography of Urban Policing. Malden, MA: Polity. . 2017. "Boredom: Accounting for the Ordinary in the Work of Policing (France)." In Writing the World of Policing: The Difference Ethnography Makes, edited by Didier Fassin, 269-92. Chicago: University of Chicago Press.

Feldman, Gregory. 2019. The Gray Zone: Sovereignty, Human Smuggling, and Undercover Police Investigation in Europe. Stanford, Calif.: Stanford University Press.

Høigård, Cecilie. 2005. "Nytt politi? en kommentert bibliografi over nyere nordisk politiforskning." Oslo: Avdeling for kriminologi og forfatteren.

Jauregui, Beatrice. 2016. Provisional Authority: Police, Order, and Security in India. Chicago: University of Chicago Press.

Karpiak, Kevin, and William Garriott, eds. 2018. The Anthropology of Police. New York: Routledge. Loftus, Bethan. 2009. Police Culture in a Changing World. New York: Oxford University Press.

Manning, Peter K., and John Van Maanen. 1978. Policing: A View from the Street. Santa Monica, CA: Goodyear.

Muir, William Ker, Jr. 1977. Police: Streetcorner Politicians. Chicago: University of Chicago Press. 
Mutsaers, Paul. 2019. Police Unlimited: Policing, Migrants, and the Values of Bureaucracy. New York: Oxford University Press.

Sausdal, David. 2014. "Cultural Culprits: Police Apprehensions of Pickpockets in Copenhagen." In Crisis and Migration: Implications of the Eurozone Crisis for Perceptions, Politics, and Policies of Migration, edited by Pieter Bevelander and Bo Petterson. Lund: Nordic Academic Press.

. 2018a. "Everyday Deficiencies of Police Surveillance: A Quotidian Approach to Surveillance Studies." Policing and Society 30(4): 462-78.

2018b. "Pleasures of Policing: An Additional Analysis of Xenophobia." Theoretical Criminology 22(2): $226-42$. . 2019a. "Policing at a Distance and That Human Thing: An Appreciative Critique of Police Surveillance." Focaal 85: 51-64. 2019b. “Terrorizing Police: Revisiting 'The Policing of Terrorism' from the Perspective of Danish Police Detectives." European Journal of Criminology, September 18.

2020a. "Everyday Policing: Toward a Greater Analytical Appreciation of the Ordinary in Police Research." Policing and Society, July 29. . 2020b. "Police Bullshit: Taking Brutal Police Talk Less Seriously." Journal of Extreme Anthropology 4(1): 94-115.

van Hulst, Merlijn. 2013. "Storytelling at the Police Station: The Canteen Culture Revisited." British Journal of Criminology 53(4): 624-42.

Van Maanen, John. 1978. “The Asshole." In Policing: A View from the Street, edited by Peter K. Manning and John Van Maanen, 221-38. Santa Monica, CA: Goodyear. 